University of Nebraska - Lincoln

DigitalCommons@University of Nebraska - Lincoln

Measuring groundwater-surface water interaction and its effect on wetland stream benthic productivity, Trout Lake watershed, northern Wisconsin, USA

\author{
Randall J. Hunt \\ U.S. Geological Survey, rjhunt@usgs.gov \\ Mac Strand \\ Northern Michigan University, rostrand@nmu.edu \\ John F. Walker \\ U.S. Geological Survey, jfwalker@usgs.gov
}

Follow this and additional works at: https://digitalcommons.unl.edu/usgsstaffpub

Part of the Earth Sciences Commons

Hunt, Randall J.; Strand, Mac; and Walker, John F., "Measuring groundwater-surface water interaction and its effect on wetland stream benthic productivity, Trout Lake watershed, northern Wisconsin, USA" (2006). USGS Staff -- Published Research. 424.

https://digitalcommons.unl.edu/usgsstaffpub/424

This Article is brought to you for free and open access by the US Geological Survey at DigitalCommons@University of Nebraska - Lincoln. It has been accepted for inclusion in USGS Staff -- Published Research by an authorized administrator of DigitalCommons@University of Nebraska - Lincoln. 


\section{Journal of \\ Hydrology}

www.elsevier.com/locate/jhydrol

\title{
Measuring groundwater-surface water interaction and its effect on wetland stream benthic productivity, Trout Lake watershed, northern Wisconsin, USA ${ }^{\text {is }}$
}

\author{
Randall J. Hunt ${ }^{\mathrm{a}, *}$, Mac Strand ${ }^{\mathrm{b}}$, John F. Walker ${ }^{\mathrm{a}}$ \\ ${ }^{\mathrm{a}}$ US Geological Survey, 8505 Research Way, Middleton, WI 53562, USA \\ ${ }^{\mathrm{b}}$ Department of Biology, Northern Michigan University, 1401 Presque Isle Avenue, Marquette, MI 49855, USA
}

Received 10 May 2005; revised 23 May 2005

\begin{abstract}
Measurements of groundwater-surface water exchange at three wetland stream sites were related to patterns in benthic productivity as part of the US Geological Survey's Northern Temperate Lakes-Water, Energy and Biogeochemical Budgets (NTL-WEBB) project. The three sites included one high groundwater discharge (HGD) site, one weak groundwater discharge (WGD) site, and one groundwater recharge (GR) site. Large upward vertical gradients at the HGD site were associated with smallest variation in head below the stream and fewest gradient reversals between the stream and the groundwater beneath the stream, and the stream and the adjacent streambank. The WGD site had the highest number of gradient reversals reflecting the average condition being closest to zero vertical gradient. The duration of groundwater discharge events was related to the amount of discharge, where the HGD site had the longest strong-gradient durations for both horizontal and vertical groundwater flow. Strong groundwater discharge also controlled transient temperature and chemical hyporheic conditions by limiting the infiltration of surface water. Groundwater-surface water interactions were related to highly significant patterns in benthic invertebrate abundance, taxonomic richness, and periphyton respiration. The HGD site abundance was $35 \%$ greater than in the WGD site and 53\% greater than the GR site; richness and periphyton respiration were also significantly greater $(p \leq 0.001,31$ and 44\%, respectively) in the HGD site than in the GR site. The WGD site had greater abundance (27\%), richness (19\%) and periphyton respiration (39\%) than the GR site. This work suggests groundwater-surface water interactions can strongly influence benthic productivity, thus emphasizing the importance of quantitative hydrology for management of wetland-stream ecosystems in the northern temperate regions.
\end{abstract}

(C) 2005 Elsevier B.V. All rights reserved.

Keywords: Groundwater-surface water interaction; Wetland; Upwelling; Benthic invertebrates; Periphyton respiration

\footnotetext{
Authors' note: Any use of trade, product, or firm names is for descriptive purposes only and does not imply endorsement by the US Government. This article is a US Government work and is in the public domain in the USA.

* Corresponding author. Fax: + 16088213817.

E-mail addresses: rjhunt@usgs.gov (R.J. Hunt), rostrand@nmu.edu (M. Strand), jfwalker@usgs.gov (J.F. Walker).
}

0022-1694/\$ - see front matter (C) 2005 Elsevier B.V. All rights reserved. doi:10.1016/j.jhydrol.2005.07.029

This article is a U.S. government work, and is not subject to copyright in the United States. 


\section{Introduction}

As one of five sites in the US Geological Survey's Water, Energy, and Biogeochemical Budgets (WEBB) Program, the Northern Temperate Lakes (NTL) WEBB project is working to understand processes controlling hydrologic and biogeochemical fluxes at different spatial and temporal scales (Walker and Bullen, 2000). The watershed hydrology of the NTLWEBB site has been investigated using groundwater flow modeling (Cheng and Anderson, 1994; Hunt et al., 1998; 2003; in press; Pint, 2002) and geochemical/ isotope tracing of water (Walker and Krabbenhoft, 1998; Walker et al., 2003). This work has shown that the variety of sources of water (terrestrial and lake recharge) can lead to complex flow systems with a variety of age and provenance occurring where groundwater discharges to the streams (Pint et al., 2003). While several single lake hydrogeologic studies from this area (e.g. Wentz and Rose, 1989; Krabbenhoft and Babiarz, 1992; Rose, 1993) have demonstrated the importance of groundwater-surface water interactions (e.g. Hurley et al., 1985; Lodge et al., 1989; Hagerthey and Kerfoot, 1998), there have been fewer studies that have focused on groundwatersurface water interaction in wetland streams. These studies have addressed the centimeter-scale hydrogeochemistry of the stream hyporheic zone (Schindler and Krabbenhoft, 1998), the effect of wetland area on nutrients exported by streams in the basin (Elder et al., 2000; 2001), and have characterized the hydrology of a single wetland system (Marin, 1986). However, in many cases there is a need to understand how these abiotic characteristics affect biological systems (Hunt and Wilcox, 2003).

Wetland streams in the Trout Lake basin typically receive appreciable groundwater inputs, including some that are focused in discrete reaches. Fisheries biologists in this region have long recognized these microhabitats as critical to brook trout (Salvelinus fontinalis), which require the relatively warm, silt-free waters of upwelling zones during winter for embryonic development (Becker, 1983) and the relatively cool summer conditions to escape temperature stress in the main channel as juveniles and adults (Biro, 1998; Baird and Krueger, 2003). Some bottomdwelling invertebrates also use upwelling zones for critical development stages (Pugsley and Hynes,
1986) and many are likely to thrive in the highly stable thermal environments (Vannote and Sweeney, 1980). Although the relation of microhabitat quality for benthic invertebrates to groundwater flow is not well documented (Boulton et al., 1998), enhanced epibenthic algae growth has been noted in this region (Hagerthey and Kerfoot, 1998) and elsewhere (Coleman and Dahn, 1990; Dent et al., 2000). Increasing algae growth with increasing groundwater flow suggests that quantity of groundwater could indirectly control the abundance and species composition of grazing invertebrates, and benthic communities in general (Ward, 1989; Boulton, 1993; Brunke and Gonser, 1997).

Productivity differences have been related to microhabitat-scale differences in groundwater flux and resulting variation in stream water temperature dynamics, sediment porosity, and nutrient transport rates (Brunke and Gonser, 1997; Dent et al., 2000; Holmes, 2000). These environmental characteristics exert a combination of direct and indirect influences on stream dwelling organisms (Hynes, 1970) that could generate inter-reach productivity gradients driven by variation in hydrologic exchange. If the influence of groundwater discharge is strong enough to create localized high-quality patches for animal populations, then reach-scale hydrologic understanding (and quantitative models) could be used to predict relative biological activity at multiple scales from site to landscape.

The purpose of this study is to assess the spatial and temporal variability of local groundwater interaction with wetland-associated streams at three sites in the Trout Lake watershed, and to relate that variability to the macroinvertebrate and periphyton communities measured at the site. This work focuses on local interactions and biological communities; implications for a larger watershed context are extrapolated from this smaller scale.

\section{Study area}

The NTL-WEBB study area is located within in the Trout Lake watershed, in the Northern Highlands Lake District of north-central Wisconsin, USA. NTLWEBB research efforts have focused primarily on Allequash Creek, a large watershed in the Trout Lake 


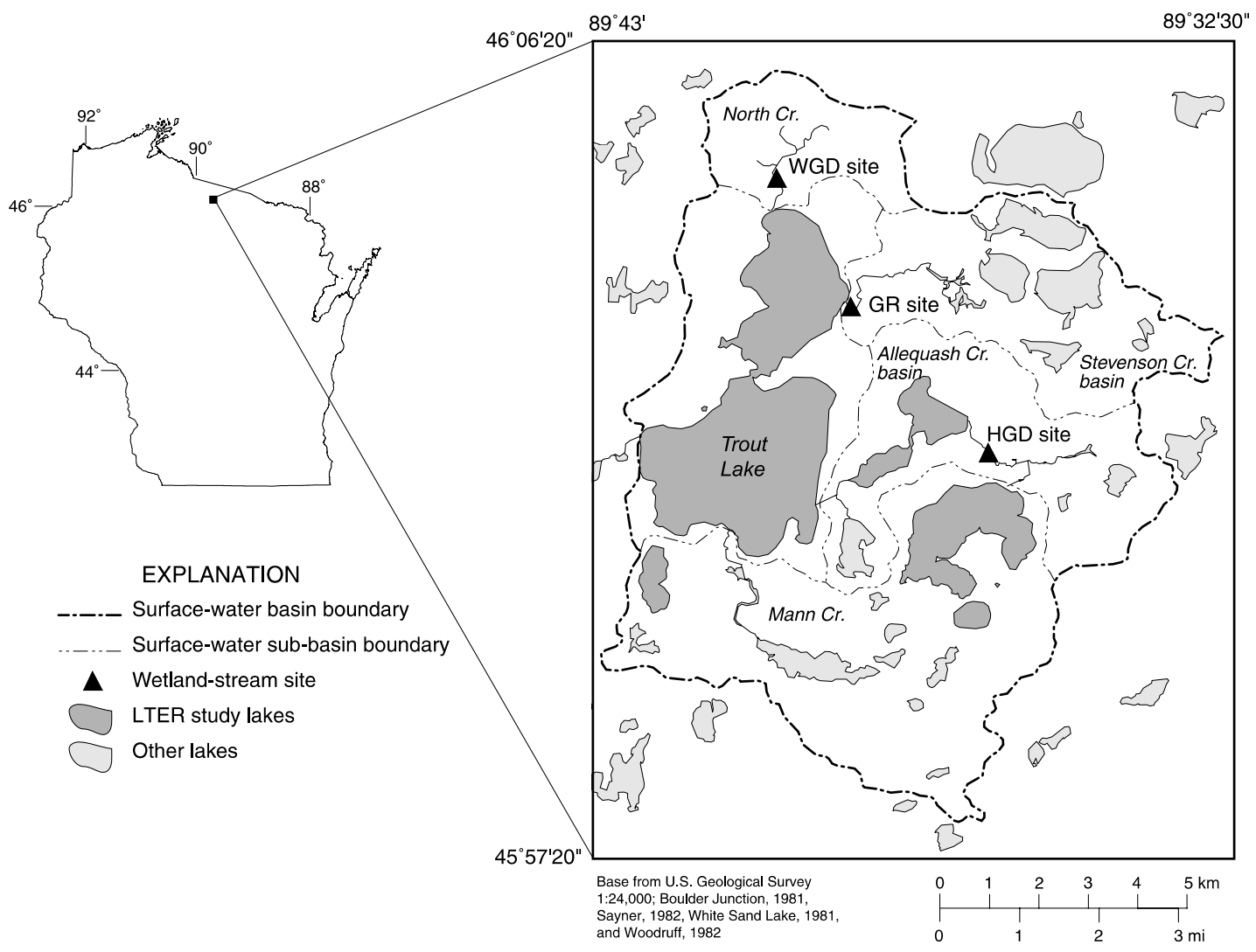

Fig. 1. Map showing location of the study area in Wisconsin (USA). Wetland-stream sites HGD, WGD, and GR refer to high groundwater discharge, weak groundwater discharge, and groundwater recharge conditions, respectively.

basin (Fig. 1), but have also included comparison studies at two other watersheds in the basin, Stevenson and North Creeks (Fig. 1). The NTL WEBB study area is co-located with one of the National Science Foundation's Long-Term Ecological Research (LTER) sites. The North Temperate Lakes LTER site is operated by the Center for Limnology at the University of Wisconsin (Magnuson et al., 1984), and focuses primarily on seven lakes in the Trout Lake area.

The Trout Lake watershed has a surface-water drainage area of 10,500 ha and ranges in elevation from approximately 490-520 m above mean sea level. Mean monthly temperatures are minimum in January, ranging from -17 to $-6{ }^{\circ} \mathrm{C}$, and are maximum in August, ranging from +13 to $+26^{\circ} \mathrm{C}$. The lakes in the area are ice-free for about 7 months per year. Precipitation averages $79 \mathrm{~cm} / \mathrm{yr}$ (Cheng and Anderson,
1994), recharge to the groundwater system averages $27 \mathrm{~cm} / \mathrm{yr}$ (Hunt et al., 1998); thus, evapotranspiration and canopy interception combined averages $52 \mathrm{~cm} / \mathrm{yr}$. As a result of precipitation being greater than evapotranspiration, the streams are dominated by groundwater discharge and baseflow comprises > 92\% of the annual streamflow (USGS, unpublished data). In addition, the poor drainage associated with the glaciated landscape results in appreciable wetland areas in the watershed, ranging from bogs to fens. The climate at the study site is affected by air masses from the North Pacific, the North Atlantic, the Gulf of Mexico, and the Arctic. Located about $70 \mathrm{~km}$ southeast of Lake Superior, and $200 \mathrm{~km}$ northwest of Lake Michigan, the NTL WEBB site is also under strong climatic influence from the Great Lakes.

The principal aquifer in the watershed is comprised of a sandy outwash plain consisting of 30-50 m of 
unconsolidated sand and gravel overlying Precambrian igneous bedrock (Okwueze, 1983; Attig, 1985). The predominant soils are thin, poorly developed, sands, loams and silts with most organic content present in the upper horizon. The glacial sediment is believed to be essentially carbonate free; thus, the groundwater chemistry is largely controlled by silicate hydrolysis (Kenoyer and Bowser, 1992; Bullen et al., 1996) and typically has low concentrations of ions and nutrients. However, extended water-mineral contact times associated with long groundwater flowpaths can result in appreciably higher ion concentrations (Walker et al., 2003; Pint et al., 2003). Moreover, shallow hyporheic areas can have appreciably higher localized concentrations than the larger groundwater system (Schindler and Krabbenhoft, 1998).

Three stream-wetland sites in the Trout Lake watershed (Fig. 1) were instrumented and operated during 2001. For clarity, sites having groundwater heads above stream stage are called 'discharge' or 'upwelling' sites; sites having groundwater heads below stream stage are called 'recharge' or 'downwelling' sites. Based on the analytic element model of Hunt et al. (1998), the sites were chosen to encompass a high groundwater discharge (HGD) at Allequash Creek, a weak groundwater discharge (WGD) at North Creek, and a groundwater recharge (GR) site at Stevenson Creek (Fig. 1). The wetland plant communities at the sites are shrub-carr and fen communities dominated primarily by Carex spp. and Alnus rugosa. Mean baseflows in the wetland streams are similar, typically ranging from about $0.09 \mathrm{~m}^{3} / \mathrm{s}$ at the GR Site to approximately $0.13 \mathrm{~m}^{3} / \mathrm{s}$ at the HGD Site (USGS, unpublished data).

Previous work has quantified stream water nutrient concentrations at these sites. The NTL-WEBB project routinely sampled the streams during 19911995, and sampled them quarterly thereafter. Using these data, Elder et al. (2001) reported similar total phosphorus and SRP yields and retentions in the Allequash, North, and Stevenson watersheds that were attributed to similar land use, geologic setting, and dominance of baseflow over storm-related runoff. Dissolved organic and inorganic carbon concentrations in stream water were also similar, and showed no trends when Allequash Creek was sampled longitudinally (Elder et al., 2000). Nitrogen

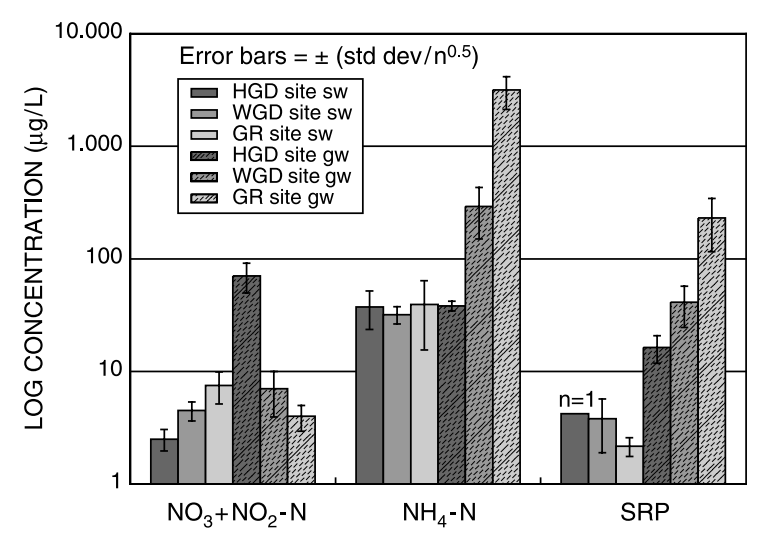

Fig. 2. Results of stream and porewater nutrient concentrations June-July 2001 (UW-Madison Center for Limnology, unpublished data). SW refers to 'surface water'; GW refers to 'groundwater'.

concentrations were also similar at the three sites (USGS, unpublished data).

Stream water samples collected during the 2001 study period showed low nutrient concentrations (Fig. 2) during June and July (University of Wisconsin, Madison Center for Limnology, unpublished data). Nitrate + Nitrite showed a slight increase from the HGD to the GR sites. Soluble reactive phosphorus (SRP) concentrations-often considered the limiting nutrient in freshwater systems-are low in the water of all three streams (Fig. 2), though concentrations appear to be lowest at the GR site. Ammonium concentrations were comparable at all three sites (Fig. 2). Stream waters are thought to be phosphorus and nitrogen limited based on a cursory nutrient limitation study at the three sites during JuneAugust 2001 (Jacques Finley, Univ. of Minnesota, written communication, September 5, 2003).

Nutrient chemistry in porewater $60 \mathrm{~cm}$ below the streams at these three sites during June and July 2001 (University of Wisconsin Center for Limnology, unpublished data) was more variable between sites, with nutrient concentrations in the groundwater higher or near the concentrations measured in the stream (Fig. 2). Moreover, a relation between groundwater velocity and groundwater porewater chemistry was observed such that the HGD site was associated with higher concentrations of nitrate plus nitrite and lower concentrations of ammonium and SRP. While relatively high, the concentrations of 
ammonium measured at the GR site were not great enough to be acutely toxic to stream biota.

The porewater results from our three sites can be compared to porewater nutrient chemistry reported by Hagerthey and Kerfoot (1998) below a lake located in the Trout Lake watershed about $7 \mathrm{~km}$ away. Lake water had nutrient concentrations lower than porewaters regardless of groundwater flow direction. They also reported lower porewater SRP concentrations in weak discharge areas and areas where lake water recharges the groundwater, which may reflect the low concentrations of the lake-water source. Similar to the relation shown in Fig. 2, they found lower ammonium porewater concentrations associated with high groundwater discharges. For comparison purposes, the GR site porewater concentrations of ammonium and SRP (Fig. 2) are higher than any value reported by Hagerthey and Kerfoot (1998); the porewater values at the HGD and WGD sites are comparable to their reported concentrations.

\section{Methods}

\subsection{Site instrumentation methods}

At each of the three sites, hydrologic instrumentation collected stream stage and temperature, water table elevation in the streambank, groundwater elevation from below the streambed, shallow groundwater temperature below the streambed, and groundwater specific conductance from a monitoring well below the streambed. Biological sampling equipment included macroinvertebrate and periphyton samplers placed on the streambed. The specifics of the installations are given below.

Stream stages were measured using a shaft potentiometer and float-counterweight system (HGD site-Allequash Creek), RDS WL-40 capacitance rod (WGD site-North Creek), and a nitrogen bubblepressure transducer system (Paroscientific PS-1 pressure transducer; GR site-Stevenson Creek). All instruments have a measurement accuracy of $\pm 0.9 \mathrm{~cm}$ or better. Stream stages were collected continuously over the study period by dataloggers; the interval of measurement was variable depending on time of year, and ranged between 1 and $6 \mathrm{~h}$. For purposes of this work, stream sediment hydraulic conductivity was assumed to be similar at each site, as expected given the relatively uniform, high conductivity, glacial outwash within the basin. As a result, groundwater discharge is assumed to be a direct function of hydraulic gradient. Actual groundwater flow will be influenced by local streambed sediment properties as well as hydraulic gradient, however, and groundwater flow is difficult to accurately measure directly. Nevertheless, temperature-profile modeling (Lapham, 1989) at the HGD and GR sites demonstrated that groundwater flow magnitude is proportional to gradient (Spitzer-List, 2003), indicating that the stream sediment properties are indeed similar.

Stream temperatures were measured approximately $1 \mathrm{~cm}$ above the stream bottom using Hobo Tidbit dataloggers; the interval of measurement for temperature ranged between $15 \mathrm{~min}$ and $1 \mathrm{~h}$ during the study period. Shallow groundwater temperatures beneath the stream were collected from thermocouples located $0.15,0.3$, and $0.9 \mathrm{~m}$ below the streambed with an interval of measurement between one and $3 \mathrm{~h}$.

Streambank water-table wells consisting of 5.1$\mathrm{cm}$-diameter PVC pipe with a 1-m screened interval were installed using a hand auger and placed so that the screen intersected the water table. At each site, two piezometers were installed below the streambed consisting of 3.2-cm-diameter stainless steel pipe with $0.3-\mathrm{m}$ stainless steel drive point screens. The piezometers were hand-driven to depth such that the bottom of the screen was placed $1 \mathrm{~m}$ below the top of the streambed sediments. Water-level measurements from the streambank and below the streambed were made at the sites using RDS WL-40 capacitance probes and Solinst Levelogger non-vented pressure transducers, respectively. One Solinst Barologger was placed at the GR site to record barometric pressure for compensating the 'unvented pressure transducers. The datalogger recording interval ranged between 2 and $6 \mathrm{~h}$ depending on time of year. In the second piezometer at each site, a Campbell Scientific temperature-specific conductance probe was installed near the screen midpoint. This instrument measured the non-purged/ambient specific conductance within the well over time. The recording interval for specific conductance measurements ranged between 1 and $3 \mathrm{~h}$.

The biota samplers used a passive approach that provided artificial substrate for colonization by: 
(1) macroinvertebrates-largely arthropods, mollusks, and annelids in these streams; and (2) periphyton-a complex of epibenthic algae, fungi, bacteria, protists, and micrometazoans in a polysaccharide matrix that coats exposed streambed surfaces (Lock et al., 1984). Multiple plate-style samplers (Flannagan and Rosenberg, 1982) anchored to the streambed with bricks were used to sample macroinvertebrates in moderately flowing sites in the three study reaches (HGD, WGD, GR sites, Fig. 1). Five samplers were employed in each reach for onemonth colonization periods. Samplers were placed in different locations within each reach from month to month. The recharge and weak discharge sites were sampled monthly from early spring through midautumn (April 1-November 4, 2001). The strong discharge site was sampled monthly from late spring through mid-autumn (May 29-November 4, 2001). Invertebrate samples were transported to the lab in $95 \%$ ethanol and picked from the samplers under $10 \times$ magnification. Invertebrates were identified to family following keys in Merritt and Cummins (1996) and Smith (2001). Thus, taxonomic richness in this study refers to the number of families present in each sample.

Periphyton respiration was measured using $\mathrm{CO}_{2}$ production. Periphyton samplers consisted of $4.8 \times$ $4.8 \mathrm{~cm}$ ceramic tiles affixed to concrete bricks with hook and loop fasteners and placed on the streambed near the invertebrate samplers. Seven to 10 tiles per site per month were employed. After one-month colonization periods, tiles were cleaned of macroscopic invertebrates in the field before they were placed in $240 \mathrm{ml}$ jars containing approximately $150 \mathrm{ml}$ of stream water and transported to the lab on ice. Once in the lab, jars were sealed with respirometry lids and placed in dark environmental chambers set at $14{ }^{\circ} \mathrm{C} . \mathrm{CO}_{2}$ efflux rate $\left(\mathrm{uL} \mathrm{CO}_{2} \mathrm{~h}^{-1}\right)$ was determined by drawing a $5 \mathrm{ml}$ headspace gas sample through a self-sealing membrane on the respirometry lid, once approximately $24 \mathrm{~h}$ after sealing and again approximately $24 \mathrm{~h}$ later. $\mathrm{CO}_{2}$ concentration was determined by injecting headspace gas samples into a CID 301 Infra-red Gas Analyzer. Five stream-water samples from each site were also analyzed each month, as were 10 deionized water controls. Efflux values from water samples were negligible in all cases and thus were excluded from the present study.

\subsection{Statistical methods}

Two approaches were used to characterize the transience in the groundwater-surface water interaction. The first is a calculation of simple statistics (standard deviation of the measurements, and the number of gradient reversals that occurred) for the study period. While generally useful, this approach does not provide information on the frequency and duration of the transient events. A second approach characterizes the distribution of periods of strong groundwater discharge to each site using techniques developed for root-zone residence-time analysis by Hunt et al. (1999). The difference between the water level in a piezometer and the water level of the stream was computed for each time step. Positive differences indicate groundwater discharge to the stream, and negative differences indicate groundwater recharge. In an effort to minimize small fluctuations in the water-level difference time series a 24-h moving average was computed. The resulting smoothed time series was analyzed to determine the length of contiguous periods where strong groundwater discharge conditions (defined by a water-level difference exceeding $4 \mathrm{~cm}$ ) existed. This resulted in a series of durations corresponding to strong discharge conditions for each piezometer. Using the standard Weibull plotting position formula the cumulative probabilities for each strong-gradient duration were determined and used to fit a log-normal distribution to the duration series. The results were plotted using a cumulative probability scale. This presentation is similar to flow duration or grain size distribution curves, but in this case steep curves reflect frequent strong-gradient events at the duration given by the $x$-axis. The duration at a given probability refers to the probability that a value will be less than the duration specified on the $x$-axis.

For statistical analyses of biotic measurements, ranked data were analyzed due to deviations from normality and/or unequal variances. Macroinvertebrate abundance (individuals per sampler), macroinvertebrate richness (number of families per sampler), and periphyton respiration data $\left(\mathrm{uL} \mathrm{CO}_{2}\right.$ per hour) for April through October samples (GR site 
vs WGD site) were analyzed with Mann-Whitney tests. Richness, abundance, and respiration data for June-October samples from all three sites were analyzed with Kruskal-Wallis tests. In all tests, the null hypothesis, i.e., samples came from the same population, was rejected when $p \leq 0.05$. Parametric alternatives to these procedures (two-sample $t$-tests and one-way ANOVAs) conducted on raw and transformed data produced identical results to the non-parametric tests.

\section{Results and discussion}

\subsection{Hydrologic differences between sites}

The sites had a range of vertical gradient between the groundwater system beneath the stream and the stream stage (Table 1), agreeing with the analytic element model results used to identify the site locations. The HGD site in Allequash Creek was the strongest discharge site as it had the largest gradient (Table 1); heads measured approximately $75 \mathrm{~cm}$ below the streambed resided, on average, $27 \mathrm{~cm}$ above stream level. The GR site in Stevenson Creek, on the other hand, was a recharge site where heads beneath the stream were on average $5 \mathrm{~cm}$ below the stream level. The WGD site in North Creek was a weaker discharge site (average head $1.8 \mathrm{~cm}$ above stream stage), and was intermediate to the HGD and GR sites.

In addition to vertical gradients which measure groundwater exchange through the stream bottom, water level data were also collected from an adjacent stream bank well ('bank well') to assess the horizontal gradient between the stream and the groundwater system. This flow can be an important component because the sediments intervening along the side of a stream channel are commonly more transmissive than the sediments underneath the stream channel. While the difference magnitude is not directly comparable because the distance to the stream edge is not constant at all sites, the variability of the water levels again is associated with groundwater flow direction (Table 1), with the GR site (the site with lowest water table relative to stream stage) having larger variability than either of the groundwater discharge sites.

In addition to the average gradients, aquatic systems may also be affected by the transience in the system. That is, how often does the system change from the average state? The strength of the groundwater driving force is relatively constant over

Table 1

Summary of 2001 hydrologic data

\begin{tabular}{llll}
\hline & HGD site & WGD site & GR site \\
\hline Streambed well-stream data & & & -0.06 \\
Mean vertical gradient & 0.35 & 0.02 & -0.07 \\
Median vertical gradient & 0.36 & 0.02 & 0.04 \\
SD vertical gradient & 0.04 & 0.02 & 4.7 \\
SD streambed gw level (cm) & 2.3 & 4.2 & 3.2 \\
SD stream stage (cm) & 4.2 & 4.3 & 48 \\
Number of gradient reversals & 0 & 238 & 3854 \\
Number of measurements & 2511 & 2434 & 0.01 \\
Bank well-stream data & & & 0.01 \\
Mean horizontal gradient & 0.04 & 0.02 & 0.02 \\
Median horizontal gradient & 0.04 & 0.02 & 6.1 \\
SD horizontal gradient & 0.01 & 0.10 & 3.8 \\
SD streambank gw level (cm) & 3.3 & 4.9 & 124 \\
SD stream stage (cm) & 4.5 & 4.3 & 2260 \\
Number of gradient reversals & 8 & 248 & gw recharge \\
Number of measurements & 1270 & 2434 & Weak gw dischg \\
Site classification & High gw dischg & & \\
\hline
\end{tabular}

HGD, high groundwater discharge; WGD, weak groundwater discharge; GR, groundwater recharge; postive values refer to flow toward the stream, negative values are flow away from the stream. 
time, as evidenced by the lowest standard deviation in the groundwater system underneath the stream $(2.3 \mathrm{~cm})$ being measured at the HGD site (Table 1). Whereas, the groundwater system is a large reservoir that provides consistent upward pressure, the GR site does not have this strong, consistent flow and is more easily affected by changes in stream stage, as is shown by the larger standard deviation $(4.7 \mathrm{~cm})$ in the streambed groundwater data (Table 1). The WGD site is again intermediate between the two other sites (Table 1). The relation of the strength of groundwater flow to the variability in the streambed heads was linear (Fig. 3), reflecting the range of stability resulting from the different degree of interaction with the large reservoir of the groundwater system. The number of vertical gradient reversals measured at the sites during 2001 was not proportional to groundwater discharge (Table 1). At the HGD site there were no reversals, at the GR site there were 48 reversals, and the WGD site had the most reversals (238) reflecting its proximity to a zero vertical gradient (Table 1, Fig. 3) - a condition where small changes in water levels can cause reversals in groundwater flow direction. A very similar ranking also is observed in the horizontal gradient reversals (Table 1). These data suggest that the ability of the surface water to horizontally and vertically infiltrate the adjacent aquifer is largest at the GR site, but the reversals of flow direction were most often found in the site with the weakest gradient (the WGD site).

The ranking of strong-gradient durations, defined here as continuous time that the 24-h moving average

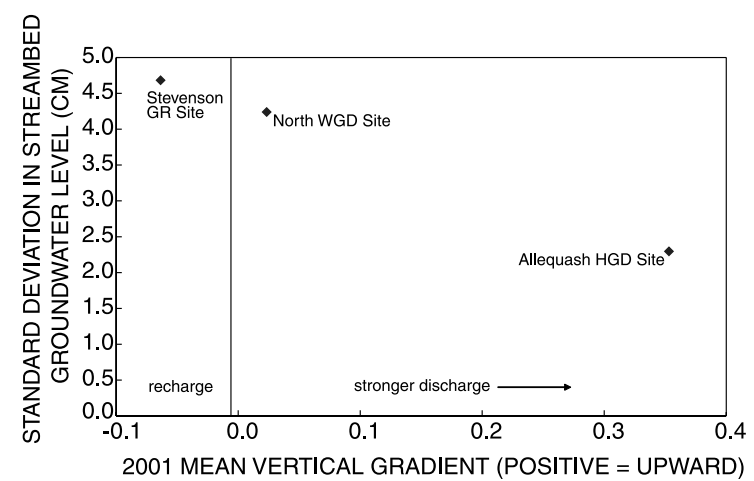

Fig. 3. Average vertical gradient between the stream and the groundwater beneath the stream is plotted against the standard deviation in the groundwater head beneath the stream.
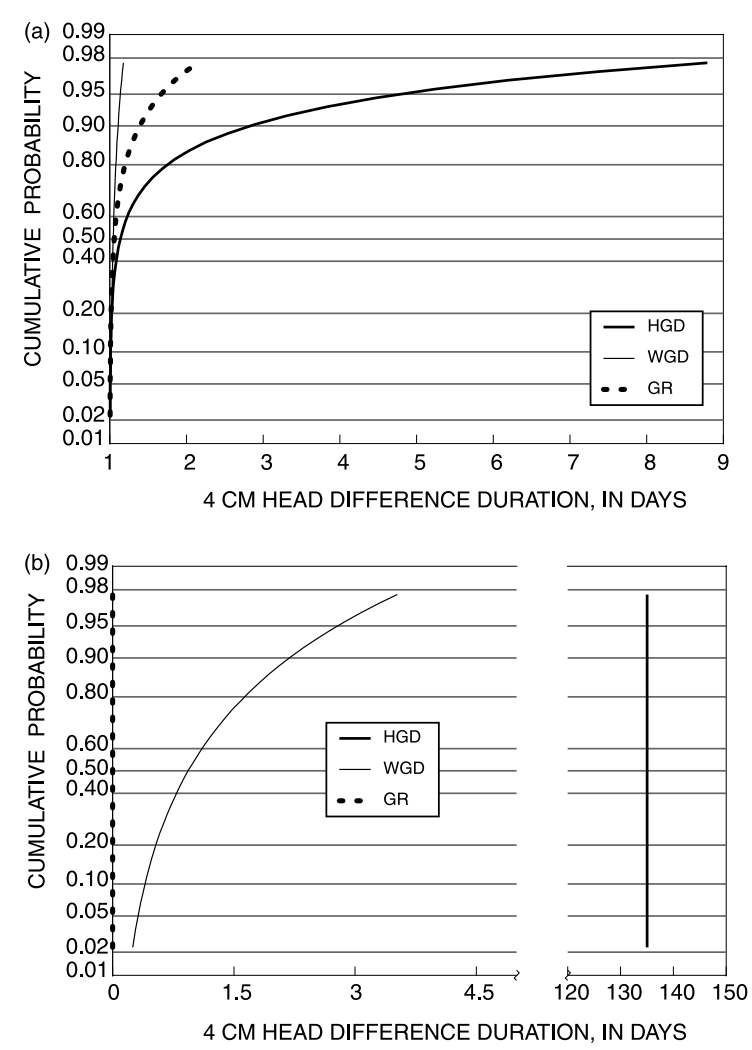

Fig. 4. Cumulative probability of the duration of strong-discharge events for horizontal (Fig. 4a) and vertical (Fig. 4b) groundwater flow.

head difference was greater than $4 \mathrm{~cm}$, was dependent on whether horizontal or vertical flow was considered (Fig. 4). For the bank wells (horizontal flow), the WGD site had the shortest strong-gradient durations, followed by the GR and HGD sites. Although the median durations (50\% probability) for GR and WGD sites are similar, the WGD is more likely to have short-duration periods than the GR site as evidenced by the divergence at the higher probability values (Fig. 4a). While the GR site is characterized by small average horizontal gradients (Table 1), the transient response of the site is characterized by longer duration periods of strong horizontal discharge than the WGD site (Fig. 4a). For the streambed piezometers (vertical flow), the ranking of strong-vertical gradient duration is related to the amount of groundwater discharge (Fig. 4b). Note that the streambed piezometer distribution at the HGD site plots as a vertical line 
with a duration equal to the monitoring period demonstrating that strong-gradient conditions existed for the entire monitoring period; the streambed piezometer distribution at GR site plots as a vertical line with a duration equal to 0 days showing stronggradient conditions were never observed during the entire monitoring period.

The strength of groundwater discharge also can control the degree of groundwater-surface water interaction, and associated transient porewater chemistry response, as shown by the measurements taken during a June 19, 2001 storm event (Fig. 5). While porewater temperature data were not available at the HGD site for this storm, the specific conductance time series also shows little effect from the storm. At the WGD site, the storm had little effect on the porewater temperature or specific conductance even though the vertical hydraulic gradient reversed multiple times during the event (Fig. 5). At the GR site, however, warm/dilute surface water derived from the storm event penetrated into the hyporheic zone, as shown by deflections in specific conductance in the streambed well and the porewater temperature profile. Interestingly, a discontinuous peat layer beneath the streambed (USGS, unpublished field notes) appears to insulate the $30-\mathrm{cm}$ thermocouple, as shown by the temperature response. Thus, the flow of infiltrating surface water, as shown by the temperature response at 15 and $91 \mathrm{~cm}$ depth, is less apparent at the $30 \mathrm{~cm}$ depth. The temperature and specific conductance time series are consistent with the hydrographs measured during this time period in that there is a downward gradient at the recharge site and upward gradients measured at the groundwater discharge sites during the storm (Fig. 5).

In addition to controlling the exchange between the hyporheic zone and the stream, groundwater discharge also affects the longer-term temperature environment of the stream system, as shown by the temperate ranges for the stream (Table 2, Fig. 6) and three depths
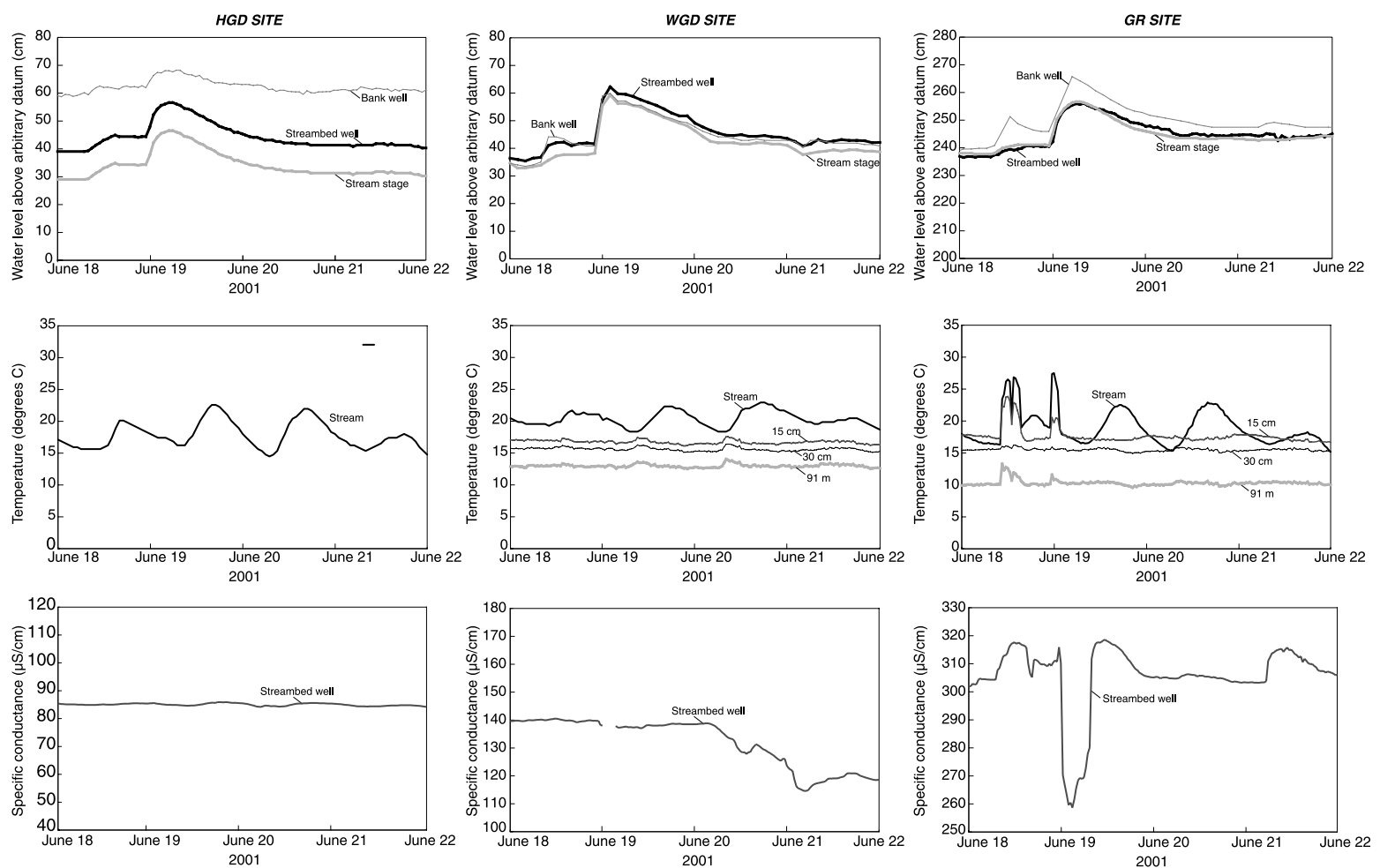

Fig. 5. Hydrographs (top row), temperature profiles (middle row), and streambed well specific conductance (bottom row) for a transient precipitation event occurring on June 18 through 19, 2001. 
Table 2

Summary of 2001 and 2002 temperature data

\begin{tabular}{|c|c|c|c|c|c|c|}
\hline & \multicolumn{3}{|c|}{ May through December 2001} & \multicolumn{3}{|c|}{ April through November 2002} \\
\hline & HGD Site & WGD Site & GR Site & HGD Site & WGD Site & GR Site \\
\hline \multicolumn{7}{|l|}{ Stream } \\
\hline Mean $\left({ }^{\circ} \mathrm{C}\right)$ & 14.4 & 16.3 & 17.3 & 15.1 & 15.3 & 16.5 \\
\hline Median $\left({ }^{\circ} \mathrm{C}\right)$ & 14.8 & 17.5 & 18.1 & 15.9 & 16.3 & 17.8 \\
\hline Std deviation $\left({ }^{\circ} \mathrm{C}\right)$ & 6.1 & 5.9 & 6.7 & 7.0 & 6.7 & 8.4 \\
\hline \multicolumn{7}{|l|}{$15 \mathrm{~cm}$ depth below stream } \\
\hline Mean $\left({ }^{\circ} \mathrm{C}\right)$ & NM & 13.9 & 14.4 & 10.3 & 11.8 & 12.6 \\
\hline Median $\left({ }^{\circ} \mathrm{C}\right.$ & NM & 14.5 & 15.6 & 10.7 & 12.8 & 13.4 \\
\hline Std deviation $\left({ }^{\circ} \mathrm{C}\right)$ & NM & 4.5 & 5.6 & 4.0 & 5.5 & 6.5 \\
\hline \multicolumn{7}{|l|}{$30 \mathrm{~cm}$ depth below stream } \\
\hline Mean $\left({ }^{\circ} \mathrm{C}\right)$ & NM & 13.6 & 13.6 & 9.1 & 11.4 & 11.7 \\
\hline Median $\left({ }^{\circ} \mathrm{C}\right)$ & NM & 15.2 & 14.6 & 9.3 & 12.3 & 12.4 \\
\hline Std deviation $\left({ }^{\circ} \mathrm{C}\right)$ & NM & 4.1 & 4.3 & 2.7 & 5.1 & 5.4 \\
\hline \multicolumn{7}{|l|}{$91 \mathrm{~cm}$ depth below stream } \\
\hline Mean $\left({ }^{\circ} \mathrm{C}\right)$ & NM & 12.6 & 11.3 & 7.5 & 10.5 & 9.7 \\
\hline Median $\left({ }^{\circ} \mathrm{C}\right)$ & NM & 13.4 & 11.5 & 7.7 & 11.2 & 9.9 \\
\hline Std deviation $\left({ }^{\circ} \mathrm{C}\right)$ & NM & 2.9 & 2.2 & 0.9 & 4.2 & 3.3 \\
\hline $\begin{array}{l}\text { Minimum number of } \\
\text { measurements distributed } \\
\text { over time period }\end{array}$ & 5136 & 4323 & 4927 & 1877 & 1878 & 5630 \\
\hline Site classification & $\begin{array}{l}\text { High gw } \\
\text { dischg }\end{array}$ & $\begin{array}{l}\text { Weak gw } \\
\text { dischg }\end{array}$ & gw recharge & $\begin{array}{l}\text { High gw } \\
\text { dischg }\end{array}$ & $\begin{array}{l}\text { Weak gw } \\
\text { dischg }\end{array}$ & gw recharge \\
\hline
\end{tabular}

HGD, high groundwater discharge; WGD, weak groundwater discharge; GR, groundwater recharge; postive values refer to flow toward the stream, negative values are flow away from the stream. NM, not measured.

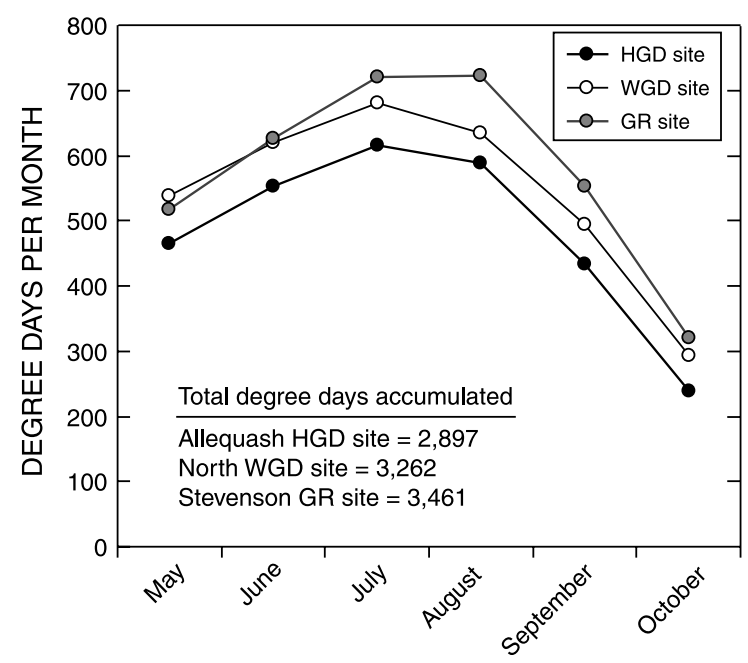

Fig. 6. Cumulative degree days (base, 0 degrees $\mathrm{C}$ ) for each site for May through October 2001.
(Table 2) below the streambed $(15,30$, and $91 \mathrm{~cm})$. Because data were not collected at the HGD site streambed during 2001, 2002 data are included for comparative purposes. The HGD and WGD sites are associated with colder temperatures (Table 2, Fig. 6) and less temperature variability in the stream and the streambed beneath the stream (Table 2). The GR site is warmer at all depths with the exception of $91 \mathrm{~cm}$ where it is slightly cooler than the WGD site. We attribute this to the presence of a peat bed between the 30 and $91 \mathrm{~cm}$ depths at the GR site. Peat sediments have relatively high insulation capacity (Hunt et al., 1996); thus, heat transport from the surface through the sediment matrix is likely reduced.

\subsection{Biological differences between sites}

A total of 23,090 macroinvertebrates representing 50 taxonomic families were collected from 90 samplers (mean, 4.74 samplers per site per month). 
Table 3

Means ( \pm 1 standard error) for macroinvertebrate abundance (individuals per sampler), macroinvertebrate richness (mean families per sampler), and periphyton respiration $\left(\mathrm{uL} \mathrm{CO}_{2} \mathrm{~h}^{-1}\right)$

\begin{tabular}{|c|c|c|c|}
\hline & HGD site (strong discharge) & WGD site (weak discharge) & GR site (recharge) \\
\hline \multicolumn{4}{|l|}{ Abundance } \\
\hline April-October & & $246 \pm 15 * * *$ & $180 \pm 30$ \\
\hline June-October & $388 \pm 34 * * *$ & $252 \pm 19 *$ & $183 \pm 37$ \\
\hline \multicolumn{4}{|l|}{ Richness } \\
\hline April-October & & $11.2 \pm 0.4 * * *$ & $9.0 \pm 0.3$ \\
\hline June-October & $12.9 \pm 0.4 * * *$ & $10.2 \pm 0.4$ (n.s.) & $8.8 \pm 0.3$ \\
\hline \multicolumn{4}{|c|}{ Periphyton respiration } \\
\hline April-October & & $11.05 \pm 1.00 * * *$ & $6.80 \pm 0.56$ \\
\hline June-October & $12.10 \pm 0.86$ (n.s.) & $11.82 \pm 1.44 * * *$ & $6.75 \pm 0.73$ \\
\hline
\end{tabular}

Asterisks presented to the right of the larger mean in each pair-wise comparison indicate significance levels for each comparison (from Mann-Whitney $U$-tests in recharge vs weak discharge and Kruskal-Wallis $H$-tests in full gradient analyses), $* * *$ indicates $p \leq 0.001$ $* p \leq 0.10(=0.055$ in only case), n.s. indicates non-significant differences. June-October 2001 data are plotted in Fig. 7 for illustrative purposes.

A total of 141 periphyton respiration samples were collected and analyzed (mean, 7.42 per site per month). Noticeable differences were noted for all measures (Table 3), although the degree of significance depended on whether the entire April-October or shortened June-October data set was used. For the entire April through October period collected at the WGD and GR sites, abundance (246 vs 180 individuals per sampler, $U=837$ vs $285, p=0.0005)$, richness (11 vs 9 families per sampler, $U=830$ vs $292, p=0.0000$ ), and respiration (11 vs $7 u \mathrm{~L} \quad \mathrm{CO}_{2}$ per hour; $U=1591$ vs $609 ; p=0.0002)$ means were larger at the WGD site than at the GR site. For the June through October period when data were collected concurrently at all three sites, abundance was much greater at the HGD site than in the WGD and GR sites (means, 388, 252, and 184 individuals per sampler, respectively, $H=31.847, p=0.0000$ ). Abundance at the WGD site was not significantly different from GR site abundance when the shorter June-October data were used at the critical rejection level of $p \leq 0.050$. However, at $p \leq 0.055$, abundance at the WGD site could be determined to be significantly greater than at the GR site, which would be consistent with the strong pattern produced when April and May data are included. Richness was much greater at the HGD site than at the WGD and GR sites during the June-October period (means, 13, 10, and 9 families per sampler, respectively, $H=830, p=0.0000)$. Respiration for the June through October period was much greater at the HGD and WGD sites than at the $\mathrm{GR}$ site $\left(12,12\right.$, vs $7 \mathrm{uL} \mathrm{CO}_{2}$ per hour, respectively, $H=19.142, p=0.0001)$.

These results were consistent with a hypothesis relating biological activity to variation in groundwater-surface water exchange. However, the causal mechanisms underlying the observed pattern are unclear at present and a topic of on-going research. Because periphyton responses generally tracked macroinvertebrate community characteristics (Table 3, Fig. 7), it is conceivable that inter-site differences in animal community composition and abundance were driven by localized increases in epibenthic productivity. If true, environmental properties resulting from quantitative variation in groundwater-surface water exchange may exert strong effects on stream life. While our data show that macroinvertebrate and periphyton quantity and quality correspond to the degree of groundwater discharge, it is well know that higher trophic levels such as brook trout would also respond to local groundwater-surface water conditions. For example, monthly degree-day temperature conditions (Fig. 6) show that average streamwater temperatures increase with decreasing groundwater discharge. Thermal stress for brook trout occurs when temperatures exceed $20^{\circ} \mathrm{C}$ (Becker, 1983). Average daily temperatures occasionally exceeded this mark in all three 
(a)

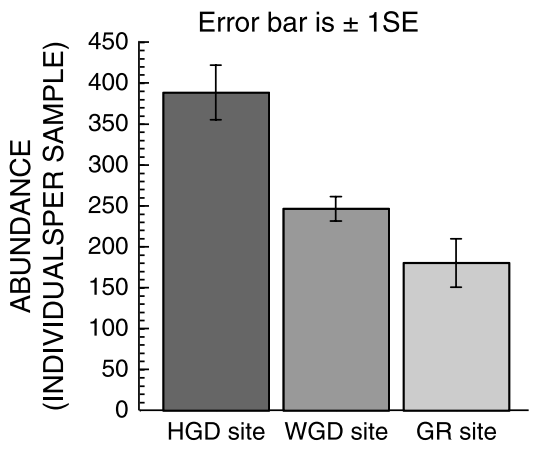

(b)

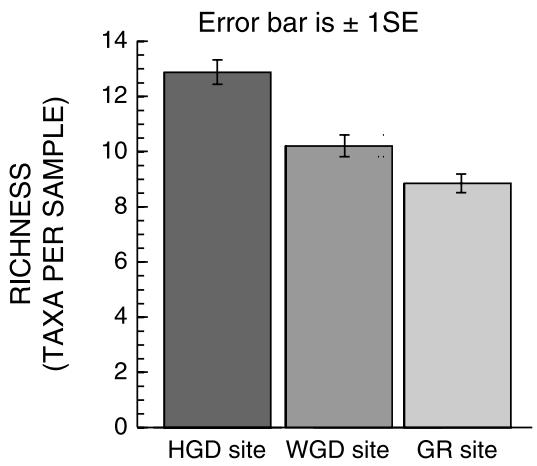

(c)

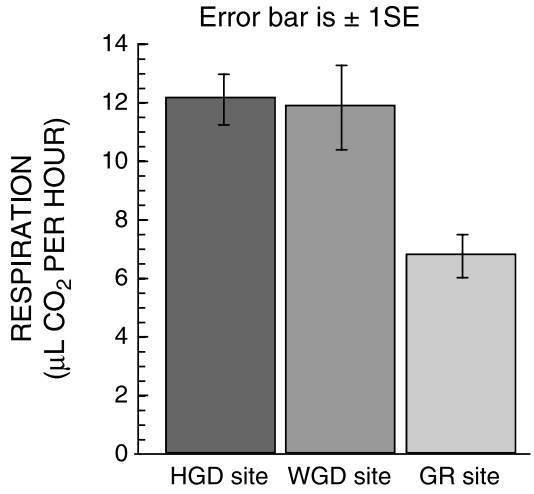

Fig. 7. Abundance and richness (macroinvertebrate samples) and respiration (periphyton samples) for June-October 2001 sampling.

sites. However, this effect was greater at the GR site (number of days, 86) than at the WGD site (69 days) and HGD site (34 days). Temperatures greater than $25^{\circ} \mathrm{C}$ are lethal to brook trout (Becker, 1983), a condition that did not occur at the HGD site, occurred 6 times at the WGD site, and 20 times at the GR site. Brook trout seek out upwelling sites during these stressful periods, which allows them to maintain body temperatures that are as much as $4{ }^{\circ} \mathrm{C}$ cooler than stream water averages (Baird and Krueger, 2003). This suggests that local availability of upwelling zones could exert control on top predator abundance in these communities.

\subsection{Implications for watershed water resources management}

Understanding the association of wetland stream benthic productivity and groundwater-surface water interaction will likely be critical as water managers move toward a more integrated understanding of the ecological system. Although the work presented here focused on wetland stream settings, the findings are of interest to many wetland types. Not all wetland streams had the same wetland habitat function (and associated biodiversity and richness) even though the wetland plant communities were similar among the sites. Rather, the site's relation to the harder-to-characterize groundwater system appeared to be an important driver. Moreover, this work demonstrates the importance of understanding the transient nature of local groundwater-surface water interaction in order to accurately characterize the drivers that control the ecological system. While this would be important for assessing wetland-specific objectives such as the loss of one wetland from the basin compared to another (and related cumulative adverse effects), it also has ramifications for scaling up results from the field scale to the watershed scale. That is, numerical groundwater flow modeling has demonstrated that the Trout Lake watershed is dominated by groundwater discharge conditions. Clearly, extrapolating biological characteristics measured at the Stevenson Creek groundwater recharge site would not be representative of the watershed as a whole. The Allequash Creek HGD site, however, is located in the area of largest hydraulic gradient in the basin. Thus, it too is likely a poor representative for the 'watershed average' condition. Based on the weaker gradients found in the basin, the intermediate weak discharge site at North Creek is likely more representative of 'average' conditions for the Trout Lake watershed. Regardless, knowledge of the groundwater flow system, and the range of possible groundwater-surface water 
interactions, can narrow the uncertainty and give bounds for what can be expected for the system as a whole. Although it is encouraging that the groundwater system can be simulated numerically (giving rise to quantitative predictions throughout the watershed), more information regarding the controlling processes that link groundwater-surface water interaction to the biotic system is needed to attain true integrated watershed management. This 'ecohydrologic' understanding of the system will likely become of primary importance as society demands more quantitative and spatially distributed answers from watershed managers.

\section{Conclusions}

As part of research conducted at one of the US Geological Survey's Water, Energy and Biogeochemical Budgets (WEBB) sites, work was undertaken to determine if variation in groundwater-surface water exchange can be used to explain observed patterns in benthic productivity. Groundwater-surface water measurements were taken at three wetland stream sites that included high groundwater discharge (HGD site on Allequash Creek), weak groundwater discharge (WGD site on North Creek), and groundwater recharge (GR site on Stevenson Creek). The major findings of this work were:

- High groundwater discharge was associated with the lowest variability in groundwater head below the stream; the groundwater recharge site had the highest variability in head beneath the stream. Horizontal and vertical gradient reversals were fewest at the HGD site, but largest at the WGD site (the site closest to zero gradient).

- The duration of strong discharge events (head difference $>4 \mathrm{~cm}$ ) differed among sites as well. The HGD site had the longest duration of strong discharge events, both for horizontal and vertical flow. The GR site had no strong discharge events for vertical flow but was intermediate for horizontal flow events. While the GR site is characterized by the smallest average horizontal gradients, the transient response of the GR site is characterized by longer duration periods of strong horizontal discharge than the WGD site.

- Groundwater discharge creates distinct temperature/chemical environs where the stability in the system is related to the amount of groundwater discharge. The hyporheic conditions are cooler and are not greatly affected by changes in the overlying surface water. At the GR site, however, changes in surface water temperature and specific conductance were transported to the hyporheic zone very quickly by infiltrating surface water.

- Groundwater-surface water interactions were related to highly significant patterns in benthic invertebrate abundance, taxonomic richness, and periphyton respiration. The HGD site abundance was $35 \%$ greater than in the WGD site and 53\% greater than the GR site; richness and periphyton respiration were also significantly greater $(p \leq 0.001,31$ and $44 \%$, respectively) in the HGD site than in the GR site. The WGD site had greater abundance (27\%), richness $(19 \%)$ and periphyton respiration (39\%) than the GR site.

- Not all wetlands had the same wetland habitat function even though the wetland plant communities were similar among the sites. Rather, the site's relation to the harder-to-characterize groundwater system appeared to be an important driver. This work also demonstrates the importance of understanding the transient nature of local groundwater-surface water interaction in order to accurately characterize the drivers that control the ecological system. While important for assessing local wetland functions, knowledge of the range of groundwater-surface water interactions operating in a watershed could also be critical for applying site-specific results to watershed-scales most often required for integrated water resources management.

These results suggest that groundwater-surface interaction can have appreciable transient characteristics and can exert significant effects on the biology of a local stream-wetland system. Moreover, this interaction is expected to vary on the watershed scale. Assessing and managing groundwater-surface water interaction within a watershed may be required to accurately assess and manage the ecological habitat in a watershed context. 


\section{Acknowledgements}

The manuscript was improved by review from Emily Stanley, Donald Rosenberry, Chuck Dunning, Tom Winter, and one anonymous reviewer. Matthew P. Ayres provided helpful discussions early in the project, helped develop the respiration methods, and lent the equipment used for making early $\mathrm{CO}_{2}$ measurements. Joseph Scanlan is acknowledged for assistance in the field and laboratory, Steve Connolly for assistance in the laboratory. This work was funded by the US Geological Survey's Northern Temperate Lakes Water, Energy, and Biogeochemical Budgets (WEBB) program.

\section{References}

Attig, J.J., 1985. Pleistocene geology of Vilas County, Wisconsin. Wisconsin Geological and Natural History Survey Information Circular 50.

Baird, O.E., Krueger, C.C., 2003. Behavioral thermoregulation of brook trout and rainbow trout: comparison of summer habitat use in an Adirondack river, New York. Transactions of the American Fisheries Society 132, 1194-1206.

Becker, G.C., 1983. The Fishes of Wisconsin. University of Wisconsin Press, Madison, WI.

Biro, P.A., 1998. Staying cool: behavioral thermoregulation during summer by young-of-year brook trout in a lake. Transactions of the American Fisheries Society 127, 212-222.

Boulton, A.J., 1993. Stream ecology and surface-hyporheic hydrologic exchange: implications, techniques and limitations. Australian Journal of Marine and Freshwater Research 44, 553-564.

Boulton, A.J., Findlay, S., Marmonier, P., Stanley, E.H., Valett, H.M., 1998. The functional significance of the hyporheic zone in streams and rivers. Annual Review of Ecology and Systematics 29, 59-81.

Brunke, M., Gonser, T., 1997. The ecological significance of exchange processes between rivers and groundwater. Freshwater Biology 37, 1-33.

Bullen, T.D., Krabbenhoft, D.P., Kendall, C., 1996. Kinetic and mineralogic controls on the evolution of groundwater chemistry and ${ }^{87} \mathrm{Sr} /{ }^{86} \mathrm{Sr}$ in a sandy silicate aquifer Northern Wisconsin, USA. Geochimica et Cosmochimica Acta 60 (10), 1807-1821.

Cheng, X., Anderson, M.P., 1994. Simulating the influence of lake position on groundwater fluxes. Water Resources Research 30 (7), 2041-2049.

Coleman, R.L., Dahn, C.N., 1990. Stream geomorphology: effects on periphyton standing crop and primary production. Journal of the North American Benthological Society 9, 293-302.

Dent, C.L., Schade, J.D., Grimm, N.B., Fisher, S.G., 2000. Subsurface influences on surface biology. In: Jones, J.B., Mulholland, P.J. (Eds.), Streams and Ground Waters. Academic Press, San Diego, CA, pp. 381-402.
Elder, J.F., Rybicki, N.B., Carter, V., Weintraub, V., 2000. Sources and yields of dissolved carbon in northern Wisconsin stream catchments with differing amounts of peatland. Wetlands 20 , 113-125.

Elder, J.F., Goddard, G.L., Homant, P.R., 2001. Phosphorus yields and retention in hydrologically distinct wetland systems in northern and southern Wisconsin (USA). Verhandlungen Internationale Vereinigung Limnologie 27, 3996-4000.

Flannagan, J.F., Rosenberg, D.M., 1982. Types of artificial substrates used for sampling freshwater benthic macroinvertebrates. In: Cairns Jr.., J. (Ed.), Artificial Substrates. Ann Arbor Sci. Publ., Ann Arbor, MI, pp. 237-266.

Hagerthey, S.E., Kerfoot, C., 1998. Groundwater flow influences the biomass and nutrient ratios of epibenthic algae in a north temperate seepage lake. Limnology and Oceanography 43 (6), $1227-1242$.

Holmes, R.M., 2000. The importance of ground water to stream ecosystem function. In: Jones, J.B., Mulholland, P.J. (Eds.), Streams and Ground Waters. Academic Press, San Diego, CA, pp. 137-148.

Hunt, R.J., Wilcox, D.A., 2003. Ecohydrology—why hydrologists should care. Ground Water 41 (3), 289.

Hunt, R.J., Krabbenhoft, D.P., Anderson, M.P., 1996. Groundwater inflow measurements in wetland systems. Water Resources Research 32 (3), 495-507.

Hunt, R.J., Anderson, M.P., Kelson, V.A., 1998. Improving a complex finite difference groundwater-flow model through the use of an analytic element screening model. Ground Water 36 (6), 1011-1017.

Hunt, R.J., Walker, J.F., Krabbenhoft, D.P., 1999. Characterizing hydrology and the importance of ground-water discharge in natural and constructed wetlands. Wetlands 19 (2), 458-472.

Hunt, R.J., Pint, C.D., Anderson, M.P., 2003. Using diverse data types to calibrate a watershed model of the Trout Lake Basin, Northern Wisconsin, in: MODFLOW and More 2003: Understanding through Modeling: Proceedings of the Fifth International Conference of the International Ground Water Modeling Center. Colorado School of Mines, Golden, CO pp. 600-604.

Hunt, R.J., Feinstein, D.T., Pint, C.D., Anderson, M.P., in press. The importance of diverse data types to calibrate a watershed model of the Trout Lake Basin, Northern Wisconsin, USA. Journal of Hydrology.

Hurley, J.P., Armstrong, D.E., Kenoyer, G.J., Bowser, C.J., 1985. Groundwater as a silica source for diatom production in a precipitation-dominated lake. Science 227, 1576-1578.

Hynes, H.B.N., 1970. The Ecology of Running Waters. University Toronto Press, Toronto, Canada.

Kenoyer, G.J., Bowser, C.J., 1992. Groundwater chemical evolution in a sandy silicate aquifer in northern Wisconsin, 1. Patterns and rates of change. Water Resources Research 28 (2), 579-589.

Krabbenhoft, D.P., Babiarz, C.L., 1992. The role of groundwater transport in aquatic mercury cycling. Water Resoures Research 28 (12), 3119-3128. 
Lapham, W.W., 1989. Use of temperature profiles beneath streams to determine rates of vertical groundwater flow and vertical hydraulic conductivity, US Geological Survey Water Supply Paper 23371989.

Lock, M.A., Wallace, R.R., Costerton, J.W., Ventullo, R.M., Charlton, S.E., 1984. River epilithon: toward a structuralfunctional model. Oikos 42, 10-22.

Lodge, D.M., Krabbenhoft, D.P., Striegl, R.G., 1989. A positive relationship between groundwater velocity and submerged macrophyte biomass in Sparkling Lake, Wisconsin. Limnology and Oceanography 34 (1), 235-239.

Magnuson, J.J., Bowser, C.J., Kratz, T.K., 1984. Long-term ecological research (LTER) on north temperate lakes of the United States. Verhandlungen Internationale Vereinigung Limnologie 22, 533-535.

Marin, L.E., 1986. Spatial and Temporal Patterns in the Hydrogeochemistry of a Bog-wetland System. M.S. University of Wisconsin-Madison, Northern Highlands Lake District, WI.

Merritt, R.W., Cummins, K.W., 1996. An Introduction to the Aquatic Insects of North America. Kendall-Hall, Dubuque, IA.

Okwueze, E., 1983. Geophysical Investigations of the Bedrock and the Groundwater-Lake Flow System in the Trout Lake Region of Vilas County. PhD Dissertation, Northern Wisconsin, University of Wisconsin, Madison, WI.

Pint, C.D., 2002. A Groundwater Flow Model of the Trout Lake Basin, Wisconsin: Calibration and Lake Capture Zone Analysis. MS thesis, Department of Geology and Geophysics, University of Wisconsin, Madison.

Pint, C.D., Hunt, R.J., Anderson, M.P., 2003. Flow path delineation and ground water age, Allequash Basin, WI. Ground Water 41 (7), 895-902.

Pugsley, C.W., Hynes, H.B.N., 1986. The three dimensional distribution of winter stonefly nymphs, Allocapnia pygmaea, within the substrate of a southern Ontario river. Canadian Journal of Fisheries and Aquatic Sciences 43, 1812-1817.
Rose, W.J., 1993. Hydrology of Little Rock Lake in Vilas County, North-Central Wisconsin, US Geological Survey WaterResources Investigations Report 93-4139 1993.

Schindler, J.E., Krabbenhoft, D.P., 1998. The hyporheic zone as a source of dissolved organic carbon and carbon gases to a temperate forested stream. Biogeochemistry 43, 157-174.

Smith, D.G., 2001. Pennak's Freshwater Invertebrates of the United States. Wiley, New York, NY.

Spitzer-List, T.M., 2003. The use of surface temperatures and temperature profiles to identify and quantify ground-water discharge and recharge areas in wetlands. MS thesis, University at Buffalo, Buffalo, $114 \mathrm{p}$.

Vannote, R.L., Sweeney, B.W., 1980. Geographic analysis of thermal equilibria: a conceptual model for evaluating the effect of natural and modified thermal regimes on aquatic insect communities. The American Naturalist 115, 667-695.

Walker, J.F., Bullen, T.D., 2000. Trout Lake, Wisconsin: a water, energy, and biogeochemical budgets program site, US Geological Survey Fact Sheet 161-99 2000.

Walker, J.F., Krabbenhoft, D.P., 1998. Groundwater and surfacewater interactions in riparian and lake-dominated systems. In: McDonnell, J.J., Kendall, C. (Eds.), Isotope Tracers in Catchment Hydrology. Elsevier, Amsterdam, The Netherlands, pp. 467-488.

Walker, J.F., Hunt, R.J., Bullen, T.D., Kendall, C., Krabbenhoft, D.P., 2003. Spatial and temporal variability of isotope and major ion chemistry in the Allequash Creek basin, northern Wisconsin. Ground Water 41 (7), 883-894.

Ward, J.V., 1989. The four-dimensional nature of lotic ecosystems. Journal of the North American Benthological Society $8,2-8$.

Wentz, D.A., Rose, W.J., 1989. Interrelationships among hydrologic-budget components of a Northern Wisconsin Seepage Lake and implications for acid-deposition modeling. Archives of Environmental Contamination and Toxicology $18,147-155$. 